\title{
The development of collective personality: the ontogenetic drivers of behavioral variation across groups
}

\author{
Sarah E. Bengston ${ }^{1 *}$ and Jennifer M. Jandt ${ }^{2}$ \\ ${ }^{1}$ Department of Ecology and Evolutionary Biology, University of Arizona, Tucson, Arizona, USA \\ ${ }^{2}$ Department of Ecology, Evolution and Organismal Biology, lowa State University, Ames, lowa, USA
}

\author{
Edited by: \\ Ann Valerie Hedrick, University of \\ California Davis, USA \\ Reviewed by: \\ Elva J. H. Robinson, University of \\ York, UK \\ Marian Yi-ling Wong, University of \\ Wollongong, Australia \\ *Correspondence: \\ Sarah E. Bengston, Department of \\ Ecology and Evolutionary Biology, \\ University of Arizona, PO Box \\ 210088 Tucson, AZ 85721-0088, \\ USA \\ e-mail: bengston@email.arizona.edu
}

For the past decade, the study of personality has become a topic on the frontier of behavioral ecology. However, most studies have focused on exploring inter-individual behavioral variation in solitary animals, and few account for the role that social interactions may have on the development of an individual's personality. Moreover, a social group may exhibit collective personality: an emergent behavioral phenotype displayed the group-level, which is not necessarily the sum or average of individual personalities within that group. The social environment, in many cases, can determine group success, which then influences the relative success of all the individuals in that group. In addition, group-level personality may itself evolve, subject to the same selection pressures as individual-level behavioral variation, when the group is a unit under selection. Therefore, we reason that understanding how collective personalities emerge and change over time will be imperative to understanding individual- and group-level behavioral evolution. Personality is considered to be fixed over an individual's lifetime. However, behavior may shift throughout development, particularly during adolescence. Therefore, juvenile behavior should not be compared with adult behavior when assessing personality. Similarly, as conditions within a group and/or the local environment can shift, group behavior may similarly fluctuate as it matures. We discuss potential within-group factors, such as group initiation, group maturation, genetic make-up of the group, and the internal social environment, and external factors, such as how local environment may play a role in generating group-level personalities. There are a variety of studies that explore group development or quantify group personality, but few that integrate both processes. Therefore, we conclude our review by discussing potential ways to evaluate development of collective personality, and propose several focal areas for future research.

Keywords: collective behavior, social groups, social insects, within-group variation, group growth

\section{DEFINING AND EVALUATING COLLECTIVE PERSONALITIES}

Non-human personality, e.g., inter-individual differences in behavior that are consistent through time, has become an increasingly popular area of study in the past decade (Koolhaas et al., 1999; Sih et al., 2004; Stamps and Groothuis, 2010; Dall et al., 2012, 2004). This may be in part because of the seemingly ubiquitous nature of animal personalities, which have been found in nearly every taxon in which they have been investigated, as well as their profound effect on behavioral plasticity and long-term fitness consequences (Sih et al., 2004; Smith and Blumstein, 2008; Stamps and Groothuis, 2010; Wray and Seeley, 2011; Jandt et al., 2014a). For example, in great tits (Parus major), there are interindividual differences in exploratory behavior ("fast" vs. "slow"; Verbeek et al., 1994; Dingemanse et al., 2002). This individual variation is both highly repeatable through time, and heritable in both wild caught and lab reared populations (Dingemanse et al., 2004, 2002). Moreover, these differences affect both adult and offspring survival, as fluctuating environmental conditions drive selection for different personality types from year to year (Dingemanse et al., 2004).
Studies measuring the development of personality tend to focus on unitary organisms and the role of early experience (DiRienzo et al., 2012), maternal effects (Groothuis et al., 2008) and persistence across life stages (Bell and Stamps, 2004). It has been shown that the consistency of personality can vary through ontogeny and upon maturation. For example, in the dumpling squid (Euprymna tasmanica), individuals are consistent in their boldness as juveniles and as adults, but are inconsistent for a period as they reach sexual maturity (Sinn et al., 2008). In yellow bellied marmots (Marmota flaviventris), boldness was only predictable in yearlings, while docility was consistent across all age classes (Petelle et al., 2013). On the other hand, lake frogs (Rana ridibunda; Wilson and Krause, 2012) and firebugs (Pyrrhocoris apterus; Gyuris et al., 2012) show consistent personality (activity and exploration, boldness and exploration, respectively) across all life stages. The flexibility of some personality traits and the persistence of others may signal that some traits may be adaptively fixed, while others are plastic so as to respond to age-specific situations (Petelle et al., 2013). 
Personality differences can also be observed at the level of the group or colony, referred to here as "collective personality." While human social groups have been the primary focus of collective personality studies (e.g., aggression or communication differences among human groups; Duncan, 1999; Hofmann and Jones, 2005; Halfhill et al., 2005), social animal groups are becoming more popular research models. Collective behavior is perhaps best understood in eusocial insects (e.g., ants, bees, wasps, and termites that exhibit cooperative brood care, overlapping adult generations and division of labor between reproductive and nonreproductive castes; Hoölldobler and Wilson, 1990). In these systems, there is selection at the colony-level (Korb and Heinze, 2004). As such, colony development has been studied extensively. However, only recently has colony-level personality been considered, and little work on the development of collective personality exists. In this review, to differentiate between eusocial and social species, we will use "colony personality" or "colony behavior" when referring to social insects, and "group personality/behavior" when referring to non-eusocial species.

Stamps and Groothuis (2010) suggest that studies measuring the development of personality fall into three categories: (1) those that measure how specific, early experiences influence adult personality, (2) those that consider if and how personality changes throughout the lifetime of an organism, and (3) how genes influence personality development. These questions can also be asked at the group-level: (1) How do events during group formation shape later group- and individual-level behavior? (2) How does group-level behavior change across group ontogeny or as the group encounters different environmental and social circumstances? (3) How is group-level behavior affected by the genotypes that comprise it? It is important to consider these questions of development at both group- and individual-levels for a variety of reasons. First, individuals and groups have different lifespans, and individuals within the group may develop at different rates or at different times during the group lifespan. Therefore, the different experiences that individuals encounter as juveniles may influence their adult personality type, and thus affect the distribution of personalities that comprise the group. Second, the relatedness among individuals and heritability of personality traits within a group are likely to further influence collective personality. For example, if there is a high broad-sense heritability of personality, then groups comprised of offspring that remain at the nest will maintain less variation in personalities than groups where heritability is low or unrelated individuals can join the group.

The distribution of individual personalities within a group can impact group performance, and thus fitness. However, the interactive dynamics of those individuals can additionally produce an emergent collective personality that differs from one calculated by only averaging the behavioral types of all individuals (Johnson and Linksvayer, 2010; Bengston and Dornhaus, 2014; LeBoeuf and Grozinger, 2014). Understanding how emergent collective personalities arise from groups of individuals is a key component to understanding how they develop. For example, if there is a centralized force influencing group behavior, such as experienced individuals guiding naïve individuals, then the personality of the individual could be much more important. Furthermore, if experienced individuals have a disproportionate influence over the group's behavior, then the growth rate of the group (and thus, the rate of new, inexperienced individuals joining the group) may be particularly important during group ontogeny, as it would alter the ratio of experienced to inexperienced individuals. Alternatively, if collective behavior is the result of a decentralized process, where individuals respond to changing conditions based upon previously established rules (innate or learned) or fluctuating feedback systems, this may either lead to more stabilized (if individual behaviors are buffered by the group; Dussutour et al., 2009; Sasaki and Pratt, 2011) or destabilized (if positive feedback processes lead to exaggeration of small effects; Sinha, 2006) collective personality.

There are few studies that investigate collective personalities (e.g., Scharf et al., 2012); most of which focus on measuring mature groups (those capable of reproducing or budding into new groups; e.g., Sasaki and Pratt, 2011; Wray and Seeley, 2011; Sasaki et al., 2013). This is likely because measuring the development of a collective unit is more complicated than measuring the development of an individual: to explore developmental factors affecting individual personality, measurements can readily be repeated on juvenile and adult individuals to determine the effects of experience or ontogeny on personality types (Bell and Stamps, 2004; Stamps and Groothuis, 2010). However, groups tend to develop at a much slower pace than individuals, and collecting or monitoring multiple groups over extended periods of time can be difficult.

Here, we discuss potential within-group (group initiation, group maturation, genetic make-up of the group, and internal social environment) and local environmental factors that may play a role in the development of collective personality in animal groups. We also highlight the importance of understanding a group's developmental phase when assessing personality type. Finally, we propose several new avenues of research that will increase our understanding of collective personalities and potentially important consequences for group fitness and adaptability, especially across changing environments.

\section{WITHIN-GROUP FACTORS}

A group's behavior emerges from the collective decisions and behaviors of individual members (e.g., the social environment). Furthermore, just like individual behaviors, group behavior can change as it matures (Figure 1; e.g., Pogonomyrmex barbatus; Gordon, 1991). In this section, we use the suggestions from Stamps and Groothuis (2010) to show how (a) group initiation (i.e., early experiences); (b) group maturation (i.e., how personality changes throughout the lifetime of the group); (c) genetic make-up of the group; and (d) internal social environment influence development of collective personality (Figure 2).

\section{GROUP INITIATION}

Depending on the species, new groups can be initiated by individual founders or by existing groups splitting into multiple smaller groups (via fission or budding) (Wilson, 1975). In groups initiated by founders, individuals have a high potential to shape future group traits by their own behavior. For example, founding individuals often choose a habitat and nest site, and rear the first generation of group members. On the other hand, groups 


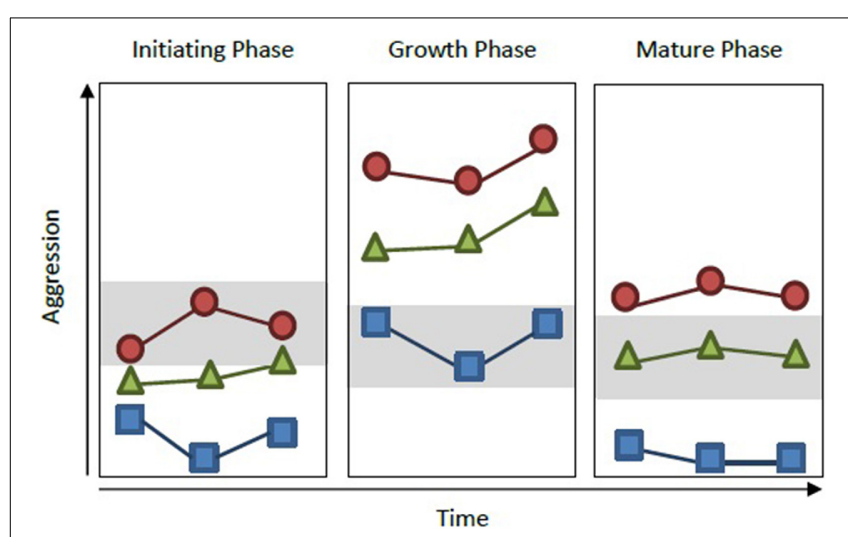

FIGURE 1 | Measuring group personality throughout development. Collective personality is typically measured on groups during one phase of development (typically either the growth or mature phase). However, personality can shift through developmental phases. In Pogonomyrmex ants, for instance, colony aggression increases during growth phase, but decreases after reaching maturity (Gordon, 1991, 1995). In the hypothetical example shown here, if measurements were taken on three different colonies (red circle, blue square, and green triangle) within and across each of these developmental phases, colonies would exhibit consistent personality differences. However, if colonies were measured only once, but at different phases of development (e.g., red circle during initiating phase, blue square during growth phase, and green triangle during mature phase), colony aggression levels would overlap significantly (gray boxes) and one would come to the incorrect conclusion that colonies do not vary in personality type.

initiated by splitting from a parent group choose a nest location and rear juveniles based on collective decisions made by the group.

The location that a founder or group chooses to establish a nest can influence colony behavior and survival (Wiernasz and Cole, 1995; Gordon and Kulig, 1996). For example, population density and availability of resources in the local environment can have a significant effect on the colony performance and personality (Gordon and Kulig, 1996; Bengston and Dornhaus, 2014) (see section Local Environment, for more detail).

A founder's personality type may also influence colony-level personality type if (1) that personality type is highly heritable and, therefore, represented among the offspring that remain at the nest, or (2), if its personality attracts joiners with particular personality types. Few studies, however, have investigated the extent to which the personality of the founder or the parent group predicts the personality of the daughter group. Two exceptions are bumble bees (Bombus terrestris) and social spiders (Anelosimus studiosus). In bumble bees, more cautious queens tend to produce colonies with more cautious workers, although founding queens tend to forage more cautiously and learn more quickly than workers (Evans and Raine, 2014). On the other hand, in social spiders, colonies grow as founders are joined by unrelated individuals. Founders that are more docile tend to attract heterospecific spiders at a faster rate. Compared to aggressive or mixed groups of both docile and aggressive founders, these mixtures of heterospecific individuals initiated by docile founders grow faster and reproduce more often (Pruitt, 2012). In this situation, group performance can be predicted by the personality of the initial founder, and group personality type can remain constant up to 3 years (Pruitt, 2012).

If personality of founders (or key individuals, see section Internal Social Environment) influence group-level personality, then group-level personality should shift when founders are replaced (either naturally or experimentally) with individuals of a different personality-type. A shift in collective behavior may be the result of the key individuals directly influencing the personality of group members already present, or the result of offspring turnover if the founder also acts as the primary reproductive in the group. Unfortunately, locating an adequate sample size of founders before or shortly after colony initiation is difficult. Therefore, research of this type is limited to species with large populations of founding individuals (e.g., foraging bumble bees or ant reproductive swarms) or those that establish their colonies in high densities in open areas (e.g., social spiders or paper wasps).

The initial personality of groups formed by budding may be more heavily influenced by the distribution of individuals that choose to split from the original group. If individuals from the original group are divided randomly, then the personality of the sister groups should mimic each other, particularly if they end up in similar environments (though groups may plastically respond to their new local environment; see section Behaviorally Plastic Responses to Environmental Shifts). However, if the group splits in a non-random fashion, for example one sister group is comprised of older, faster, or more aggressive individuals, then one collective unit may have a very different personality than the other (Modlmeier et al., 2014a). There are indeed significant personality differences observed among house-hunting colonies (i.e., swarms of individuals that recently split from the original group) of honey bees (Apis mellifera) (Wray and Seeley, 2011). However, it is unclear whether those differences are the result of non-random assortment of individuals that join the swarm (Grozinger et al., 2014), and whether the composition of those individuals creates a collective personality that differs from a sister colony.

\section{GROUP MATURATION}

The analogy between individual and group development is most apparent in eusocial insects, where selection occurs at the level of the colony. Like individuals with germ (reproductive) and somatic (non-reproductive) cells, colonies are comprised of reproductive (queen) and non-reproductive (worker) individuals (Wilson, 1985; Szathmáry and Smith, 1995). Furthermore, colonies grow, mature, reproduce, and disperse; and fitness is achieved not when new individuals are produced, but when a new colony is initiated (Wilson, 1985).

Throughout development, collective behavior may shift with the changing needs of the group (Figure 1). For example, grouplevel behavior can change as group size increases-a trend observed across eusocial taxa (Dornhaus et al., 2012). In honeybees, even though some colonies are consistently more aggressive than others (Pearce et al., 2001; Hunt, 2007), aggression levels increase with colony size (Wray et al., 2011), and/or when resources become scarce (Downs and Ratnieks, 2000). This trend of increased aggression with colony size or state of maturation 


\begin{tabular}{|c|c|c|c|}
\hline & Mechanism of Development & & Predicted Collective Behavior \\
\hline \multicolumn{4}{|l|}{ Group Initiation } \\
\hline Solitary Founder & $\begin{array}{l}\text { Groups grow as a founder is } \\
\text { joined by unrelated } \\
\text { (sometimes heterospecific) } \\
\text { individuals and/or as } \\
\text { offspring remain at the nest. }\end{array}$ & $\frac{\pi}{2 \pi}$ & $\begin{array}{l}\text { Collective behavioral phenotype } \\
\text { can be predicted by the } \\
\text { personality of the initiating } \\
\text { founder, but does not necessarily } \\
\text { mimic her personality type. }\end{array}$ \\
\hline Group Budding & $\begin{array}{l}\text { Groups grow until they reach } \\
\text { a critical size. At that point, a } \\
\text { subset of individuals splits off } \\
\text { to form a new group. }\end{array}$ & मn & $\begin{array}{l}\text { Personality of old and new groups } \\
\text { likely differ due to non-random } \\
\text { assortment of individuals that } \\
\text { leave or remain with the group. }\end{array}$ \\
\hline \multicolumn{4}{|l|}{ Group Maturation } \\
\hline $\begin{array}{c}\text { Geprowth } \\
\text { Dispersal }\end{array}$ & $\begin{array}{l}\text { Group needs change as they } \\
\text { grow and reproduce. }\end{array}$ & & $\begin{array}{l}\text { New / small groups require less } \\
\text { resources and may be shyer, less } \\
\text { prone to risky behavior. More } \\
\text { established / large groups may be } \\
\text { bolder, more aggressive (but see } \\
\text { Gordon 1991). }\end{array}$ \\
\hline \multicolumn{4}{|l|}{ Genes } \\
\hline $\begin{array}{l}\text { Gen } \\
\text { Dive }\end{array}$ & $\begin{array}{l}\text { A colony founded by a } \\
\text { multiply mated (polyandrous) } \\
\text { queen, or a group joined by } \\
\text { unrelated individuals will } \\
\text { result in a genetically diverse } \\
\text { composition of individuals. } \\
\end{array}$ & & $\begin{array}{l}\text { Genetically diverse groups tend to } \\
\text { be faster growing, healthier, and } \\
\text { in some cases, better able to } \\
\text { withstand perturbations in the } \\
\text { environment. }\end{array}$ \\
\hline \multicolumn{4}{|l|}{ Social Environment } \\
\hline $\begin{array}{l}\text { Interactions } \\
\text { with Juveniles }\end{array}$ & $\begin{array}{l}\text { Adults can differentially feed } \\
\text { or manipulate juveniles, } \\
\text { influence their growth rate, } \\
\text { gene expression, and } \\
\text { hormonal titers. }\end{array}$ & $\infty$ & $\begin{array}{l}\text { Adults vary in behavioral } \\
\text { responses and reproductive } \\
\text { potential. Group behavior is } \\
\text { dependent upon the distribution } \\
\text { of these differences. }\end{array}$ \\
\hline $\begin{array}{l}\text { Interactions } \\
\text { with Nestmates }\end{array}$ & $\begin{array}{l}\text { Nestmates can share food, } \\
\text { groom, and alert each other } \\
\text { to new food via odor, quality, } \\
\text { and in some cases, location. }\end{array}$ & & $\begin{array}{l}\text { Individuals that interact with } \\
\text { nestmates returning with food } \\
\text { might deliver that food to } \\
\text { immobile juveniles or leave the } \\
\text { nest to search for more. An } \\
\text { efficient division of labor can } \\
\text { boost group level performance. }\end{array}$ \\
\hline Key Individuals & $\begin{array}{l}\text { A few highly aggressive or } \\
\text { active individuals in a group } \\
\text { will react more quickly or } \\
\text { more strongly to stimuli than } \\
\text { others. }\end{array}$ & & $\begin{array}{l}\text { Key individuals can } \\
\text { disproportionately shift collective } \\
\text { phenotype to be more active or } \\
\text { aggressive, for example, than if } \\
\text { those key individuals were absent. }\end{array}$ \\
\hline
\end{tabular}

FIGURE 2 | Development of collective personalities. Collective personality development can manifest itself in multiple ways-through group initiation, group maturation, genes, and social environment. 
is true for many species, including wasps (yellowjacket wasps: Vespula spp., Akre et al., 1976; paper wasps: Polistes spp., Hunt, 2007), but cannot be generalized across all social insect taxa. For example, in the red harvester ant (Pogonomyrmex barbatus), aggression levels actually decrease as colony size increases (Figure 1; Gordon, 1991) and in Temnothorax ruagatulus ants aggression is completely unrelated to colony size (Bengston and Dornhaus, 2014).

Provisioning of juveniles may also fluctuate as the group matures, creating different experiences for developing individuals, a factor that could influence the variation of individual personalities in the group. For example, founding termite queens of Reticulitermes speratus lay fewer, but larger, eggs early in the colony cycle when the queen has less time to devote to brood care. Later in the colony cycle when workers are available to forage and tend brood, the queen will switch and begin laying more eggs of a smaller size that take longer to develop than the larger eggs (Matsuura and Kobayashi, 2010). To determine whether changes observed in early vs. late workers are due to egg size or the differential social environment in which eggs are reared (i.e., with or without workers), insect eggs can be collected from nests and grafted onto different regions of the nest or placed back in the nest at different points of the colony cycle. If this difference in early rearing environment (in terms of resources available to the egg) influences worker development (and thus personality), large eggs reared later in the colony cycle should exhibit personalities similar to those reared early. Alternatively, if the stage of the colony cycle, and/or the different interactions with founders and siblings, has a stronger influence on the development of individual personality, then offspring reared early and late in the colony cycle would develop very different personality types, regardless of egg size.

In Polistes wasps, there is a clear shift in the way queens interact with developing larvae that develop early vs. late in the colony cycle. Early in the colony cycle, Polistes fuscatus queens provision larvae with less food and drum their antennae on the nest while feeding larvae. Those larvae develop into workers that will forage and tend the second cohort of brood (Hunt, 2007; Suryanarayanan et al., 2011a). The second brood cohort receives more food as larvae but no drumming. They develop into the next generation of queens that do not engage in colony tasks but instead conserve their energy to overwinter (Hunt, 2007; Suryanarayanan et al., 2011a). Further, when this drumming is artificially delivered to nests later in the colony cycle, developing larvae react to the vibrational interactions by developing less fat stores, a physiological trait more similar to that of workers (Suryanarayanan et al., 2011b). In both the termite and wasp examples, the differential interactions that adults have with developing juveniles, both behaviorally and nutritionally, can affect a large change in collective behavior, and possibly the collective personality observed at the colony-level. The next step will be to tease apart the relative role that behavior, nutrition, and other environmental factors may play on the development of different personality types in individuals, how those personalities correlate across populations, and how that corresponds to collective personalities observed in different environments.

\section{GENETIC MAKE-UP OF THE GROUP}

Personality traits can vary in heritability (e.g., $h^{2}: 0.01-0.014$, stickleback aggression; 0.66, chimpanzee dominance, Weiss et al., 2000; reviewed in van Oers et al., 2005). Therefore, the extent that founders predict the personality of a group comprised of offspring that remain at the nest or kin that co-found or join the nest likely varies across taxa. Further, as cooperating founders are often unrelated (e.g., fire ants: Solenopsis invicta, Bernasconi and Keller, 1999; paper wasps: Polistes spp., Jandt et al., 2014b, social spiders: Anelosimus studiosus, Pruitt and Goodnight, 2014) or solitary foundresses can be polyandrous (i.e., multiply mated) (e.g., honeybees: Apis mellifera, leaf-cutter ants: Acromyrmex spp., red harvester ants: Pogonomyrmex badius; reviewed in Oldroyd and Fewell, 2007), relatedness of individuals within a group can vary. Social heterosis (Nonacs and Kapheim, 2007, 2008), a process whereby genetically dissimilar individuals benefit by outperforming groups of genetically similar individuals, has been observed in social organisms from microbes (Vos and Velicer, 2006) to primates (Wooding et al., 2006). Increased genetic variation may result in faster growing, healthier, and perhaps more homeostatic groups better able to withstand perturbations in the environment (reviewed in Oldroyd and Fewell, 2007). In species that co-found with related individuals, such as the facultatively social bee, Exoneura robusta, strong reproductive skew can exist, with skew positively correlated to increased relatedness between reproductives (Harradine et al., 2012). This is a pattern seen in many social mammals as well, in which a dominant matriarch produces a disproportionate majority of the offspring (meerkats: Suricata suricatta, Clutton-Brock et al., 2001; marmots: Marmota spp., Allainé, 2000; naked mole rats: Heterocephalus glaber, Clarke and Faulkes, 1997); though the mechanism underlying this reproductive skew may vary. In these systems, increased relatedness is expected to offset the skew and costs of cooperation (Hamilton, 1964).

The genetic composition of individuals within the group may have indirect genetic effects on other group members as well. For example, in a group of Drosophilia males, aggressive behavior (influenced by genotype) of one individual can influence the interactions between the others, and impact mating success (Saltz, 2013). Therefore, understanding the genetic make-up of the group, and how that changes over time, may influence the developmental trajectory of the collective personality.

Within the group, behavioral variation in threshold sensitivity, due to heritable and gene expression differences (Box 1; Figure 3), may influence how a group divides and performs tasks (Beshers and Fewell, 2001), and how it responds as a collective unit (Jandt and Dornhaus, 2014; LeBoeuf and Grozinger, 2014). For example, a honeybee's predisposition to collect nectar or pollen is partially based on a genetic predisposition to recognize sugar (e.g., their sucrose thresholds; Page et al., 2012). Colonies bred to maintain individuals with particularly high or low thresholds to respond to sucrose (pollen vs. sucrose foraging personalities, respectively, see Jandt et al., 2014a) will themselves develop a nectar or pollen foraging collective personality (Page and Fondrk, 1995; Page et al., 2012). In this case, if the queen were to be replaced with one bred to exhibit the opposite sensory threshold, the collective foraging personality of that colony would 


\section{Box 1 | From the genome to the sociome and back.}

Variation in gene expression is a mechanism that can produce behavioral variation among individuals-even among highly related individuals-within a group (Toth and Robinson, 2007; Zayed and Robinson, 2012). There are a number of studies that show a correlation between gene expression and long-term developmental differences (physiological and behavioral) in individuals (Toth et al., 2009; Page et al., 2012; Dolezal and Toth, 2014). For example, novelty-seeking behavior (i.e., scouting for new nest sites or food resources by the same individuals as colony needs change) in honey bees correlates with a down-regulation of a dopamine receptor gene in the brain (Liang et al., 2012), a pattern similar to that observed in mammals (Viggiano et al., 2002).

Changes in gene expression throughout a lifetime can also be a mechanism that allows individuals to transition between behavioral states (Dolezal and Toth, 2014). Indeed, in honey bees, behavioral transitions across tasks (often referred to as task polyethism) correlate with widespread changes in brain gene expression (Whitfield et al., 2003, 2006; Alaux et al., 2009). At least some of these changes in gene expression appear to precede changes in behavior and some have been demonstrated to have causal influences on individual behavioral tendencies (Page et al., 2012). The social environment, including colony maturation, can also have a profound influence on an individual's gene expression (honey bees Apis mellifera, Grozinger et al., 2003; Wang et al., 2008; fire ants Solenopsis invicta, Manfredini et al., 2013; paper wasps Polistes metricus, Toth et al., 2014), and it is the dynamic interplay between the genome and the social environment (a field referred to as "sociogenomics") that makes the development of colony-level behavior so complex and fascinating (Figure 3).

As an individual develops, its gene expression can change, both between and within life stages (e.g., Whitfield et al., 2006; Hoffman and Goodisman, 2007; Toth et al., 2014). In adult social insects for example, changes in the expression of cGMP-dependent protein kinase (PKG) affect the probability that an individual will forage (honey bees Apis mellifera, Ben-Shahar et al., 2002); red harvester ant Pogonomyrmex barbatus (Ingram et al., 2005); yellowjacket wasp Vespula vulgaris (Tobback et al., 2008). These changes can be brought on by abiotic (e.g., light or temperature), developmental (e.g., changes in hormone titers during development), or social factors (e.g., pheromone exposure, interactions with other insects). Furthermore, in honey bees, where colonies can vary quite dramatically in aggressive personalities (Pearce et al., 2001), exposing an individual to an alarm pheromone can result in the up-regulation of several genes involved in biogenic amine signaling (similar to that observed in vertebrates, Nelson and Chiavegatto, 2001), which in turn results in increased aggression or defensive behavior exhibited by the individual (Alaux et al., 2009). In both of these examples, changes among individuals can lead to changes in the social regulation, and thus possibly the personality, of the colony (Page et al., 2012). Therefore, gene expression differences among individuals may have consequences for the extended phenotype of colony personality.

There is evidence that many gene networks or functional pathways associated with social behaviors, such as brood care, aggression, and dominance, are conserved across animal taxa (e.g., overlap in molecular pathways found in wasps, honeybees, flies, and mice; Toth et al., 2014, 2010). Although the degree to which "personality genes" are conserved across all animal taxa is unknown, given the ubiquitous nature in which personality is observed across taxa, it is likely. To date, at least one gene has been directly associated with an individual personality in social insects (dopamine receptor in novelty-seeking honeybees; Liang et al., 2012). Whether such genes affect collective personality, and could therefore be considered "collective personality genes," is a distinct possibility.

gradually shift with the change in the genotype of the colonyoffspring of the original genotype would be gradually replaced with offspring of the new genotype.

Division of labor within a colony, in general, has been described as a major contributor to the ecological success of eusocial groups, such as ants (Wilson, 1987; Wilson and Hölldobler, 2005). As colonies develop and the needs of the group change, tasks may be allocated among individuals differently such that the relative proportion of individuals engaging in particular tasks (i.e., foraging vs. guarding) may change (Gordon, 1995; LeBoeuf and Grozinger, 2014). Furthermore, variation in individual personality types within a group can facilitate division of labor (Holbrook et al., 2014). Because division of labor observed at the colony level is partially influenced by the differential gene expression of individuals in the group, changes in gene expression throughout an individual's development will affect their task preference. Therefore, as colonies develop and individuals mature, dynamics of division of labor and colony phenotype will shift, a factor that could have significant impact on the collective personality (Figure 3). Therefore, the division of labor, and how that changes throughout development, is likely to impact the collective personality of the group. This prediction can be tested by removing specialists or cohorts of individuals particularly efficient at performing group tasks and quantifying the collective personality of what is left of the group after they have begun working again (e.g., Jandt and Dornhaus, 2014).

\section{INTERNAL SOCIAL ENVIRONMENT}

The social environment can influence the production of withingroup variation by affecting gene expression or hormone titers in developing individuals, predisposing them to exhibit specific personalities as adults (see Box 1). Within groups, these individual differences can influence group performance (Modlmeier and Foitzik, 2011; Pruitt and Riechert, 2011; Pamminger et al., 2012), division of labor (LeBoeuf and Grozinger, 2014), and also likely collective personality (Modlmeier et al., 2014a).

In some social groups, the repeated interactions of individuals may drive the level of behavioral variation within the group via a process known as social niche specialization (Montiglio et al., 2013). For example, in the social spider, Stegodyphus mimosarum, longer group tenure leads to higher variation in boldness between individuals, and higher individual consistency in boldness (Laskowski and Pruitt, 2014). A similar pattern was found in S. dumicola spiders, despite having an independent evolutionary origin of sociality (Modlmeier et al., 2014c). These studies suggest that as a group matures, the flexibility of individual behaviors may decline, perhaps stabilizing overall group behaviors (though not if large perturbation cause groups to mix and re-form; Modlmeier et al., 2014c). However, social niche 


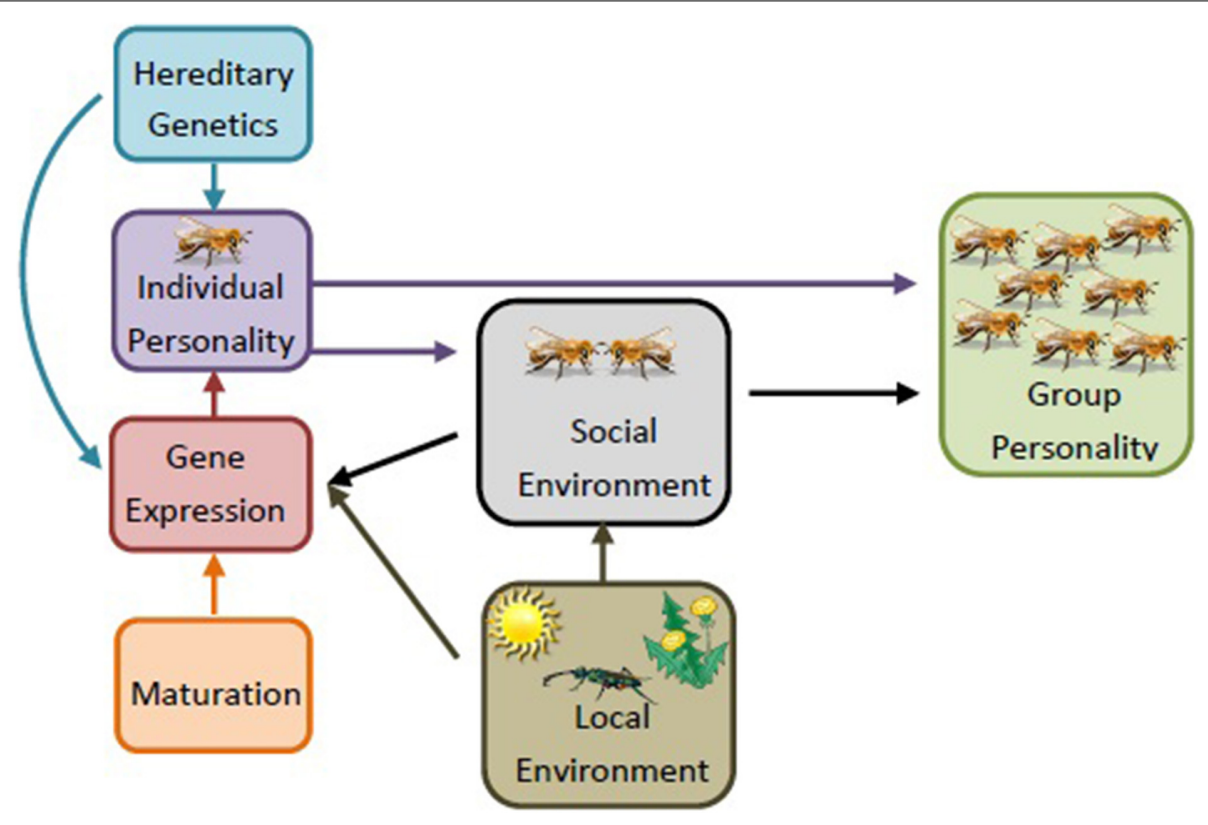

FIGURE 3 | Sociogenomics of personality. An individual's personality develops from a combination of hereditary genetics and differential gene expression. The group-level personality, then, is influenced by a combination of individual personalities and the social interactions among individuals (e.g., social environment). The social environment, age, and local environment (e.g., presence of parasites and predators, food availability/consistency, variation in climate) can influence the gene expression of the individual. These changes can influence an individual's personality, and therefore the social environment, leading to a change in group level personality. Local environment can also influence social environment, though less is known about these mechanisms. The development of the group is an adaptive, dynamic process, constantly shifting as the demographics of the group, such as age structure and group needs, change. For simplicity, regulatory elements and epigenetics are here lumped into the category "gene expression," but with the recognition that these factors play significant roles in shaping the individual's phenotype as well (figure adapted from Dolezal and Toth, 2014). specialization is not a ubiquitous trait. For example, studies of stickleback fish (Gasterosteus aculeatus, Laskowski and Bell, 2014) and meerkats (Suricata suricatta, Carter et al., 2014) show no evidence for it. It is currently unknown why some social groups develop social niches while others do not; though social niches are expected in groups with relatively stable social structures (i.e., little fission or fusion). Within a group, it has been shown that specific genotypes may predispose some individuals to occupy specific social niches over others (Saltz, 2013; Saltz and Nuzhdin, 2014). Genetic variation is also one proximate explanation for division of labor in social insects (Page and Robinson, 1991; Robinson, 1992; Beshers and Fewell, 2001; LeBoeuf and Grozinger, 2014). While division of labor and social niche specialization likely are intertwined and feed back upon each other, the specifics of this relationship are thus far unknown and provide a promising area of future research.

Furthermore, in some groups, one or a few "key" individuals (also referred to as "keystone", Modlmeier et al., 2014b; "elites", Pinter-Wollman et al., 2012b; "leaders", Conradt and Roper, 2003) can have disproportionate influence on the behaviors of others in the group (for a full review see Modlmeier et al., 2014b). Over time, as groups grow in size, the influence of key individuals may change, resulting in significant changes in the collective personality. Hormone mediated interactions are largely presumed to be the mechanism by which key individuals influence the group (Modlmeier et al., 2014b). This may be episodic, such as the hormonal changes among individuals following dominance conflicts
(Jandt et al., 2014b), or more permanent, such as pheromones exuded by the alpha female that suppress reproductive development in subordinate group members (Richard and Hunt, 2013).

Experimental removal or replacement of key individuals can be used to illustrate the degree to which those individuals influence the personality of a group, and/or personality of individuals within that group. In the zebrafish (Danio rerio), removal of key individuals with high social centrality decreases overall performance in learning group-foraging skills (Vital and Martins, 2013). In other groups, key individuals may simply maintain or improve social order and cohesion, such as bottlenose dolphins (Tursiops truncatus, Lusseau and Newman, 2004) and pigtailed macaques (Macaca nemestrina, Flack et al., 2006). However, not all key individuals provide a benefit to the group. In yellow baboons (Papio cynocephalus), the presence of a hyper-aggressive individual can drastically increase the level of stress hormones and decrease lymphocyte production in other individuals within the group (Alberts et al., 1992).

In most cases, key individuals are measured in mature groups. As such, it is not clear when these individuals first appear in group ontogeny. It is possible that the group must be a certain size before key individuals become highly influential. Alternatively, individuals may need to have a specific length of tenure in a group before becoming disproportionately important. As their presence or absence can be highly influential to group behavior, an obvious next step is to understand how key individuals originate (Modlmeier et al., 2014b). 


\section{LOCAL ENVIRONMENT}

In addition to the factors that drive the development of collective personality within the group, experience from the local environment plays an important role as well (e.g., Pinter-Wollman et al., 2012a). Indeed, in guinea pigs (Cavia aperea), the length of the photoperiod juveniles are exposed to predicts their resting metabolic rates, cortisol levels and fearlessness through ontogeny (Guenther et al., 2014). In tarantulas (Brachypelma smithi), juveniles reared with environmental enrichment form a correlated suite of four behaviors that reflect a bold personality; whereas those reared under minimal conditions form a correlation between only two traits (Bengston et al., 2014). These examples challenge the assumption that personality is fixed, particularly when environmental conditions vary throughout an organism's (or group's) lifetime (Stamps and Groothuis, 2010). A group's lifetime may be considerably longer than that of a single individual, so different age cohorts of individuals may experience different environmental interactions. Therefore, the group as a collective unit would have been exposed to a wider variety of local conditions than a single individual within the group. Further, even if only a few individuals alter their behavior based on changes in the local environment (e.g., fluctuating temperatures or food availability, predation risk, etc.), this may suffice to alter the dynamics driving overall collective behavior (see section Internal Social Environment).

\section{BEHAVIORALLY PLASTIC RESPONSES TO ENVIRONMENTAL SHIFTS}

Ecologically relevant factors in the local environment can significantly impact collective behavior in highly social species. For example, the ant Temnothorax longispinosus is susceptible to attacks from the parasitic brood-robbing (slavemaking) ant Protomognathus americanus. The presence of $P$. americanus can increase colony-level aggression in T. longispinosus, a response not seen when exposed to non-parasitic competitors (Pamminger et al., 2011). Moreover, P. americanus founding queens have more successful invasions against less aggressive colonies, suggesting that the presence of this species may act as a selective agent for an aggressive response (Pamminger et al., 2012). The increased aggressive response disappeared after 14 days, suggesting that this personality trait may be temporary or is primarily the result of behavioral plasticity (Pamminger et al., 2011). In the arid social spider Stegodyphus dumicola, colonies are able to plastically adjust their collective foraging behavior when introduced to a new environment. However, it is not an immediate response. Rather, the colonies are able to respond more rapidly to prey after being in the new environment longer (Keiser et al., 2014).

Individual variation can still persist, however, even when there is plasticity in group-level response to environmental variability. For example, black harvester ant colonies (Messor andrei) maintain significant inter-colony differences in both foraging and response to disturbance, even though they flexibly adjust their movement speed in response to humidity (Pinter-Wollman et al., 2012a). A similar pattern is seen in red harvester ant colonies (Pogonomyrmex barbatus), which also show consistent inter-colony differences in foraging behavior, but will decrease their rate of foraging behavior in dry conditions (Gordon et al., 2013). Flexibly adjusting to humidity is a selectively advantageous trait, as desiccation costs are high for these desert foraging ants (Gordon, 2013). This implies that while different colony-level personality types can be maintained within a population, colonies can be flexible in their responses to environmental conditions.

\section{BEHAVIORALLY FIXED RESPONSES TO ENVIRONMENTAL SHIFTS}

Plasticity may allow groups to track environmental variation in the short term, but it is relatively unknown if exposure to environmental conditions can create fixed or long-term effects on collective personality. In the ant Temnothorax rugatulus, colonylevel risk-tolerance, as reflected by foraging effort and defensive response, varies across a longitudinal gradient (Bengston and Dornhaus, 2014). Examination of the local environment revealed risk tolerance level is well predicted by competition for nest sites, and aggression is affected by how closely clustered the nest sites are (SE Bengston, unpublished data). It is unknown if this is the result of local adaptation due to natural selection or if colonies are able to assess colony density and respond accordingly. In the closely related species, T. longispinosus, colonies also exhibit higher levels of aggression and productivity as the population becomes more crowded (Modlmeier and Foitzik, 2011). Manipulating colony density does not affect defensive behavior, suggesting this behavior, which may be due to local adaptation, is fixed in these populations (Pamminger et al., 2012). Similarly, in the social spider, Anelosimus studiosus (Pruitt and Goodnight, 2014), colonies maintain an ideal group composition of behavioral phenotypes that varies between populations. If perturbed from the ideal, colonies either perish or return to the ideal mixture, though exactly how groups correct their compositions is yet unknown. In this example as well, colonies in different populations may be locally adapted to exhibit a specific collective personality type. These personality types remain fixed and are imperative to the survival of the group in that region. Therefore, while having the ability to plastically respond to changing environments may be beneficial, in more environmentally stable regions, having a fixed behavioral group-level phenotype would have selective advantages as well.

\section{FUTURE DIRECTIONS}

The development of collective personality truly presents a new frontier to those interested in both personality and collective behavior. We propose several areas of focus to initiate research that may illuminate understanding of how collective personalities of social organisms develop.

\section{FITNESS EFFECTS}

Collective personalities have consequences for both group- and individual-level fitness. Depending on the degree to which individuals within the group are related, the heritability of personality traits, and the social structure of the group, the way in which selection acts at the individual- and group-level may vary. The different mechanisms that can drive collective personality may further compound the fitness effects on individuals and/or the group. For example, if the collective personality of a newly founded colony (with only a few individuals) can be influenced by the personality type of a key individual, the success or failure of that new colony, and all the individuals in it, may be closely tied 
to the fate of that single individual. This is the case for the social spider Stegodyphus dimucola, where the presence of just one key individual leads to an increase in body weight for the rest of the colony by $400 \%$, and an increase in individual colony member survivorship by $30 \%$ (Keiser et al., 2014).

Few studies specifically explore the fitness consequences of maintaining collective personality differences in a population, and no study to date has explored the fitness consequences of maintaining consistent personalities throughout group development. If behavior of the group shifts to respond to changing needs during different developmental phases (Figure 1), what are the fitness consequences to these behavioral shifts? If group personality becomes less consistent during specific developmental phases, as it does during the adolescent phase in squid (Sinn et al., 2008), what are the fitness consequences of having less consistency for short periods of group development? Are groups more vulnerable at stages of their development when personality is more or less consistent?

Measuring group-level fitness is not a trivial process. In eusocial insects, for example, fitness could be measured as the production of new queens and males, but a more accurate measure of fitness would consider the number of new colonies initiated by those new queens (Wilson, 1985). However, the success rate of new queens founding colonies can be low (Aron et al., 2009; Pull et al., 2013), and dependent upon many variables (e.g., climate conditions, predator/parasite density, availability of nesting sites, etc.,) (Voss and Blum, 1987; Tschinkel, 1993; Bernasconi and Keller, 1999). Still, group-level fitness can be measured in multiple ways. As mentioned above, fitness could be measured as the number of new groups initiated in 1 year or throughout the group's lifetime. However, this may be difficult, as daughter groups may be hard to track and monitor in the field, or establish in the lab (though not impossible; see Gordon, 2013; Pruitt, 2013). Additionally, fitness could be measured by proxies such as group mass, survivorship, or ability to avoid predation or parasitism (Keiser et al., 2014). Moreover, these factorsgrowth, survivorship, and reproduction-could be affected by personalities on different axes, so it is important to consider multiple-dimensions of personality, both among individuals and colonies.

\section{STABILITY OF COLLECTIVE PERSONALITIES}

Collective personalities may be more prone to instability than individual personalities. Migration in or out of the group, individual turnover, or fluctuation in the ratio of experienced to inexperienced individuals, for example, will affect the social environment and may alter the collective behaviors, and thus the personality, of the group (Figure 3). If the shift in behavior with individual turnover through group development is a mechanism that allows colonies to adapt to changing environments, then groups with faster rates of turnover should out-compete those with slower rates of turnover. On the other hand, groups with more consistency in collective personality may out-compete groups with higher rates of turnover in fixed environments.

A collective personality may also become more stable as a group matures if an increase in the number of individuals within a group decreases the "noise" from the variation within the group. In studies on collective decision-making, groups of individuals often make better decisions than solitary individuals; a phenomenon described as "wisdom of crowds" (Simons, 2004; Conradt and List, 2009). As group size increases, the efficiency of this decision-making can also change (Sasaki and Pratt, 2011; Kao and Couzin, 2014). When more individuals sample the environment, the group is provided with more information and may be better able to plastically alter their behavior or otherwise maintain adaptive stability (Raine and Chittka, 2007). If this is similarly affected by group size, it may be even more important during ontogeny as the group grows (Dornhaus et al., 2012).

The degree to which a group is fixed or stable under varying environmental conditions, or as the group size increases, may itself be an important characteristic that varies in a population. Therefore, understanding how consistent group-level behavior is across developmental stages is not the only important factor to consider. The degree to which groups plastically respond to disturbance, as well as the degree to which this is adaptive under a given environmental type, will also be an important area for future studies understanding collective personality.

\section{COLLECTIVE REACTION NORMS}

Individuals of the same genotype may behave differently in different environments (Gordon, 2013). The interaction between environment and genotype and its effect on phenotypic plasticity, often referred to as a reaction norm, is a common consideration in personality research. Though the mechanisms may be more complex, and thus difficult to quantify, behavioral reaction norms may still affect how collective personality is studied. For example, the level of genotypic variation within a group may influence the plasticity of emergent behaviors. As such, more highly related groups may vary more predictably between environments, while groups formed by unrelated aggregations may vary more erratically. Alternatively, increased within-group genetic variation may result in greater homeostasis. That is, although individuals with different genotypes may vary in response to perturbations in the environment, groups with greater genetic diversity may be more resilient and respond more consistently as environmental conditions fluctuate (Oldroyd and Fewell, 2007).

As groups grow and change in composition (of both personality type and genotype), the genotype by environment interaction may shift. This may allow groups to more plastically react to environmental conditions, or conversely destabilize adaptive responses as emergent behaviors are formed. Furthermore, these group-level reaction norms may vary across species that occupy similar habitats and/or across populations. Future research that accounts for the local environment, genotype, and degree to which groups respond appropriately to perturbations throughout development will provide a comprehensive understanding of collective personality.

\section{CONCLUSIONS}

Collective personality is a relatively new area of focus for behavioral ecologists. As such, there is limited evidence for precise mechanisms or selective agents. However, our understanding of how collective behaviors emerge and how group-level differences are maintained has provided a strong platform with which 
hypotheses can be drawn and tested. Here, we summarized what is known about the within-group and environmental factors that may influence collective personality through ontogeny, and propose potential new avenues of research.

In this review there has been a strong bias toward studies with social insects as the focal species, which reflects the current state of the literature. Arthropods, and in particular those species that live in groups, are ideal to test hypotheses that address the evolution of sociality. Unlike vertebrates, arthropods tend to have shorter generation times, and a variety of tools are available to study the internal developmental mechanisms (e.g., fixed neural pathways or epigenomic factors) that affect the personality type expressed by an individual (Kralj-Fišer and Schuett, 2014). As a result, social invertebrate colonies are particularly useful to study colony personality, and more specifically, the development of colony personality. In many cases, the entire colony cycle can be monitored from initiation throughout maturation (Ingram et al., 2005; Gordon, 2013; Pruitt, 2013), as well as across multiple generations.

However, with growing interest in collective personality, researchers should begin considering how other social groups develop and maintain collective personalities. Though selection may act more strongly on the level of the individual in noneusocial species, group personality still holds implications for individual-level fitness by affecting overall group performance. It is our hope that the theory presented here will be used generally, and the lessons learned to understand collective personality in social insects can be applied to other social groups.

In conclusion, researchers must be cautious to consider environmental context when assessing behavioral changes over time, as they may be due to long term individual changes in early development or circumstantial changes that are tracking current environmental conditions. Recognizing the role that group age, stage of development, social environment, heritability, and environmental pressures have on group-level phenotype is the first step to understanding and assessing important group-level differences. When groups exhibit differences in personality type, then indeed there may be significant ecological implications for selection of personality types within groups. These implications could stretch across multiple levels of organization, including populations and individuals, making group personalities relevant to all social animals.

\section{ACKNOWLEDGMENTS}

We wish to thank Anna Dornhaus, Amy Toth, Jonathan Pruitt, Noa Pinter-Wollman, Andreas Modlmeier, and Nick DiRienzo, as well as members of the Dornhaus lab (University of Arizona, U.S.), and the Toth lab (Iowa State University, U.S) for helpful discussions and feedback on the manuscript.

\section{REFERENCES}

Akre, R. D., Garnett, W. B., Donald, J. F. M., Greene, A., and Landolt, P. (1976). Behavior and colony development of Vespula pensylvanica and V. atropilosa (Hymenoptera: Vespidae). J. Kans. Entomol. Soc. 49, 63-84.

Alaux, C., Sinha, S., Hasadsri, L., Hunt, G. J., Guzmán-Novoa, E., DeGrandiHoffman, G., et al. (2009). Honey bee aggression supports a link between gene regulation and behavioral evolution. Proc. Natl. Acad. Sci. U.S.A. 106, 15400-15405. doi: 10.1073/pnas.0907043106
Alberts, S. C., Sapolsky, R. M., and Altmann, J. (1992). Behavioral, endocrine, and immunological correlates of immigration by an aggressive male into a natural primate group. Horm. Behav. 26, 167-178. doi: 10.1016/0018-506X(92) 90040-3

Allainé, D. (2000). Sociality, mating system and reproductive skew in marmots: evidence and hypotheses. Behav. Processes 51, 21-34. doi: 10.1016/S03766357(00)00116-9

Aron, S., Steinhauer, N., and Fournier, D. (2009). Influence of queen phenotype, investment and maternity apportionment on the outcome of fights in cooperative foundations of the ant Lasius niger. Anim. Behav. 77, 1067-1074. doi: 10.1016/j.anbehav.2009.01.009

Bell, A. M., and Stamps, J. A. (2004). Development of behavioural differences between individuals and populations of sticklebacks, Gasterosteus aculeatus. Anim. Behav. 68, 1339-1348. doi: 10.1016/j.anbehav.2004.05.007

Bengston, S. E., and Dornhaus, A. (2014). Be meek or be bold? A colony-level behavioural syndrome in ants. Proc. R. Soc. B Biol. Sci. 281:20140518. doi: 10.1098/rspb.2014.0518

Bengston, S. E., Pruitt, J. N., and Riechert, S. E. (2014). Differences in environmental enrichment generate contrasting behavioural syndromes in a basal spider lineage. Anim. Behav. 93, 105-110. doi: 10.1016/j.anbehav.2014.04.022

Ben-Shahar, Y., Robichon, A., Sokolowski, M. B., and Robinson, G. E. (2002). Influence of gene action across different time scales on behavior. Science 296, 741-744. doi: 10.1126/science.1069911

Bernasconi, G., and Keller, L. (1999). Effect of queen phenotype and social environment on early queen mortality in incipient colonies of the fire ant, Solenopsis invicta. Anim. Behav. 57, 371-377. doi: 10.1006/anbe.1998.0955

Beshers, S., and Fewell, J. (2001). Models of division of labor in social insects. Annu. Rev. Entomol. 46, 413-440. doi: 10.1146/annurev.ento.46.1.413

Carter, A. J., English, S., and Clutton-Brock, T. H. (2014). Cooperative personalities and social niche specialization in female meerkats. J. Evol. Biol. 27, 815-825. doi: $10.1111 /$ jeb. 12358

Clarke, F. M., and Faulkes, C. G. (1997). Dominance and queen succession in captive colonies of the eusocial naked mole-rat, Heterocephalus glaber. Proc. R. Soc. Lond. B Biol. Sci. 264, 993-1000. doi: 10.1098/rspb.1997.0137

Clutton-Brock, T. H., Brotherton, P. N. M., Russell, A. F., O’Riain, M. J., Gaynor, D., Kansky, R., et al. (2001). Cooperation, control, and concession in meerkat groups. Science 291, 478-481. doi: 10.1126/science.291.5503.478

Conradt, L., and List, C. (2009). Group decisions in humans and animals: a survey. Philos. Trans. R. Soc. B Biol. Sci. 364, 719-742. doi: 10.1098/rstb.2008.0276

Conradt, L., and Roper, T. J. (2003). Group decision-making in animals. Nature 421, 155-158. doi: 10.1038/nature01294

Dall, S. R. X., Bell, A. M., Bolnick, D. I., and Ratnieks, F. L. W. (2012). An evolutionary ecology of individual differences. Ecol. Lett. 15, 1189-1198. doi: 10.1111/j.1461-0248.2012.01846.x

Dall, S. R. X., Houston, A. I., and McNamara, J. M. (2004). The behavioural ecology of personality: consistent individual differences from an adaptive perspective. Ecol. Lett. 7, 734-739. doi: 10.1111/j.1461-0248.2004.00618.x

Dingemanse, N. J., Both, C., Drent, P. J., and Tinbergen, J. M. (2004). Fitness consequences of avian personalities in a fluctuating environment. Proc. R. Soc. Lond. B Biol. Sci. 271, 847-852. doi: 10.1098/rspb.2004.2680

Dingemanse, N. J., Both, C., Drent, P. J., van Oers, K., and van Noordwijk, A. J. (2002). Repeatability and heritability of exploratory behaviour in great tits from the wild. Anim. Behav. 64, 929-938. doi: 10.1006/anbe.2002.2006

DiRienzo, N., Pruitt, J. N., and Hedrick, A. V. (2012). Juvenile exposure to acoustic sexual signals from conspecifics alters growth trajectory and an adult personality trait. Anim. Behav. 84, 861-868. doi: 10.1016/j.anbehav.2012. 07.007

Dolezal, A. G., and Toth, A. L. (2014). Honey bee sociogenomics: a genome-scale perspective on bee social behavior and health. Apidologie 45, 375-395. doi: 10.1007/s13592-013-0251-4

Dornhaus, A., Powell, S., and Bengston, S. (2012). Group size and its effects on collective organization. Annu. Rev. Entomol. 57, 123-141. doi: 10.1146/annurevento-120710-100604

Downs, S. G., and Ratnieks, F. L. W. (2000). Adaptive shifts in honey bee (Apis mellifera L.) guarding behavior support predictions of the acceptance threshold model. Behav. Ecol. 11, 326-333. doi: 10.1093/beheco/11.3.326

Duncan, L. E. (1999). Motivation for collective action: group consciousness as mediator of personality, life experiences, and women's rights activism. Polit. Psychol. 20, 611-635. doi: 10.1111/0162-895X.00159 
Dussutour, A., Beekman, M., Nicolis, S. C., and Meyer, B. (2009). Noise improves collective decision-making by ants in dynamic environments. Proc. R. Soc. B Biol. Sci. 276, 4353-4361. doi: 10.1098/rspb.2009.1235

Evans, L. J., and Raine, N. E. (2014). Changes in learning and foraging behaviour within developing bumble bee (Bombus terrestris) colonies. PLoS ONE 9:e90556. doi: 10.1371/journal.pone.0090556

Flack, J. C., Girvan, M., de Waal, F. B. M., and Krakauer, D. C. (2006). Policing stabilizes construction of social niches in primates. Nature 439, 426-429. doi: 10.1038/nature04326

Gordon, D. M. (1991). Behavioral flexibility and the foraging ecology of seed-eating ants. Am. Nat. 138, 379-411. doi: 10.1086/285223

Gordon, D. M. (1995). The development of organization in an ant colony. Am. Sci. $83,50-57$.

Gordon, D. M. (2013). The rewards of restraint in the collective regulation of foraging by harvester ant colonies. Nature 498, 91-93. doi: 10.1038/nature 12137

Gordon, D. M., Dektar, K. N., and Pinter-Wollman, N. (2013). Harvester ant colony variation in foraging activity and response to humidity. PLoS ONE 8:e63363. doi: 10.1371/journal.pone.0063363

Gordon, D. M., and Kulig, A. W. (1996). Founding, foraging, and fighting: colony size and the spatial distribution of harvester ant nests. Ecology 77, 2393-2409. doi: $10.2307 / 2265741$

Groothuis, T. G. G., Carere, C., Lipar, J., Drent, P. J., and Schwabl, H. (2008). Selection on personality in a songbird affects maternal hormone levels tuned to its effect on timing of reproduction. Biol. Lett. 4, 465-467. doi: 10.1098/rsbl.2008.0258

Grozinger, C. M., Richards, J., and Mattila, H. R. (2014). From molecules to societies: mechanisms regulating swarming behavior in honey bees (Apis spp.). Apidologie 45, 327-346. doi: 10.1007/s13592-013-0253-2

Grozinger, C. M., Sharabash, N. M., Whitfield, C. W., and Robinson, G. E. (2003). Pheromone-mediated gene expression in the honey bee brain. Proc. Natl. Acad. Sci. U.S.A. 100, 14519-14525. doi: 10.1073/pnas.2335884100

Guenther, A., Finkemeier, M.-A., and Trillmich, F. (2014). The ontogeny of personality in the wild guinea pig. Anim. Behav. 90, 131-139. doi: 10.1016/j.anbehav.2014.01.032

Gyuris, E., Feró, O., and Barta, Z. (2012). Personality traits across ontogeny in firebugs, Pyrrhocoris apterus. Anim. Behav. 84, 103-109. doi: 10.1016/j.anbehav.201 2.04.014

Halfhill, T., Nielsen, T. M., Sundstrom, E., and Weilbaecher, A. (2005). Group Personality composition and performance in military service teams. Mil. Psychol. 17, 41-54. doi: 10.1207/s15327876mp1701_4

Hamilton, W. D. (1964). The genetical evolution of social behaviour. I. J. Theor. Biol. 7, 1-16. doi: 10.1016/0022-5193(64)90038-4

Harradine, S. L., Gardner, M. G., and Schwarz, M. P. (2012). Kinship in a social bee mediates ovarian differentiation and has implications for reproductive skew theories. Anim. Behav. 84, 611-618. doi: 10.1016/j.anbehav.2012.06.016

Hoffman, E. A., and Goodisman, M. A. (2007). Gene expression and the evolution of phenotypic diversity in social wasps. BMC Biol. 5:23. doi: 10.1186/1741-70 07-5-23

Hofmann, D. A., and Jones, L. M. (2005). Leadership, collective personality, and performance. J. Appl. Psychol. 90, 509-522. doi: 10.1037/0021-9010.90.3.509

Holbrook, C. T., Wright, C. M., and Pruitt. J. N. (2014). Individual differences in personality and behavioural plasticity facilitate division of labour in social spider colonies. Anim. Behav. 97, 177-183. doi: 10.1016/j.anbehav.2014.09.015

Hoölldobler, B., and Wilson, E. O. (1990). The Ants. Cambridge, MA: Harvard University Press. doi: 10.1007/978-3-662-10306-7

Hunt, J. H. (2007). Evolution of Social Wasps. Oxford, UK: Oxford University Press. Ingram, K. K., Oefner, P., and Gordon, D. M. (2005). Task-specific expression of the foraging gene in harvester ants. Mol. Ecol. 14, 813-818. doi: 10.1111/j.1365294X.2005.02450.x

Jandt, J. M., Bengston, S., Pinter-Wollman, N., Pruitt, J. N., Raine, N. E., Dornhaus, A., et al. (2014a). Behavioural syndromes and social insects: personality at multiple levels. Biol. Rev. 89, 48-67. doi: 10.1111/brv.12042

Jandt, J. M., and Dornhaus, A. (2014). Bumblebee response thresholds and body size: does worker diversity increase colony performance? Anim. Behav. 87, 97-106. doi: 10.1016/j.anbehav.2013.10.017

Jandt, J. M., Tibbetts, E. A., and Toth, A. L. (2014b). Polistes paper wasps: a model genus for the study of social dominance hierarchies. Insectes Sociaux 61, 11-27. doi: 10.1007/s00040-013-0328-0
Kao, A. B., and Couzin, I. D. (2014). Decision accuracy in complex environments is often maximized by small group sizes. Proc. R. Soc. B Biol. Sci. 281:20133305. doi: $10.1098 / \mathrm{rspb} .2013 .3305$

Keiser, C. N., Modlmeier, A. P., Singh, N., Jones, D. K., and Pruitt, J. N. (2014). Exploring how a shift in the physical environment shapes individual and group behavior across two social contexts. Ethology 120, 825-833. doi: 10.1111/eth. 12256

Koolhaas, J. M., Korte, S. M., De Boer, S. F., Van Der Vegt, B. J., Van Reenen, C. G., Hopster, H., et al. (1999). Coping styles in animals: current status in behavior and stress-physiology. Neurosci. Biobehav. Rev. 23, 925-935. doi: 10.1016/S01497634(99)00026-3

Korb, J., and Heinze, J. (2004). Multilevel selection and social evolution of insect societies. Naturwissenschaften 91, 291-304. doi: 10.1007/s00114-004-0529-5

Kralj-Fišer, S., and Schuett, W. (2014). Studying personality variation in invertebrates: why bother? Anim. Behav. 91, 41-52. doi: 10.1016/j.anbehav.2014.02.016

Laskowski, K. L., and Bell, A. M. (2014). Strong personalities, not social niches, drive individual differences in social behaviours in sticklebacks. Anim. Behav. 90, 287-295. doi: 10.1016/j.anbehav.2014.02.010

Laskowski, K. L., and Pruitt, J. N. (2014). Evidence of social niche construction: persistent and repeated social interactions generate stronger personalities in a social spider. Proc. R. Soc. B Biol. Sci. 281:20133166. doi: 10.1098/rspb.2013.3166

LeBoeuf, A. C., and Grozinger, C. M. (2014). Me and we: the interplay between individual and group behavioral variation in social collectives. Curr. Opin. Insect Sci. 5, 16-24. doi: 10.1016/j.cois.2014.09.010

Liang, Z. S., Nguyen, T., Mattila, H. R., Rodriguez-Zas, S. L., Seeley, T. D., and Robinson, G. E. (2012). Molecular determinants of scouting behavior in honey bees. Science 335, 1225-1228. doi: 10.1126/science.1213962

Lusseau, D., and Newman, M. E. J. (2004). Identifying the role that animals play in their social networks. Proc. R. Soc. Lond. B Biol. Sci. 271, S477-S481. doi: 10.1098/rsbl.2004.0225

Manfredini, F., Riba-Grognuz, O., Wurm, Y., Keller, L., Shoemaker, D., and Grozinger, C. M. (2013). Sociogenomics of cooperation and conflict during colony founding in the fire ant Solenopsis invicta. PLoS Genet 9:e1003633. doi: 10.1371/journal.pgen.1003633

Matsuura, K., and Kobayashi, N. (2010). Termite queens adjust egg size according to colony development. Behav. Ecol. 21, 1018-1023. doi: 10.1093/beheco/arq101

Modlmeier, A. P., and Foitzik, S. (2011). Productivity increases with variation in aggression among group members in Temnothorax ants. Behav. Ecol. 22, 1026-1032. doi: 10.1093/beheco/arr086

Modlmeier, A. P., Keiser, C. N., Shearer, T. A., and Pruitt, J. N. (2014a). Speciesspecific influence of group composition on collective behaviors in ants. Behav. Ecol. Sociobiol. 68, 1929-1937. doi: 10.1007/s00265-014-1799-3

Modlmeier, A. P., Keiser, C. N., Watters, J. V., Sih, A., and Pruitt, J. N. (2014b). The keystone individual concept: an ecological and evolutionary overview. Anim. Behav. 89, 53-62. doi: 10.1016/j.anbehav.2013.12.020

Modlmeier, A. P., Laskowski, K. L., DeMarco, A. E., Coleman, A., Zhao, K., Brittingham, H. A., et al. (2014c). Persistent social interactions beget more pronounced personalities in a desert-dwelling social spider. Biol. Lett. 10:20140419. doi: 10.1098/rsbl.2014.0419

Montiglio, P.-O., Ferrari, C., and Réale, D. (2013). Social niche specialization under constraints: personality, social interactions and environmental heterogeneity. Philos. Trans. R. Soc. B Biol. Sci. 368:20120343. doi: 10.1098/rstb.2012.0343

Nelson, R. J., and Chiavegatto, S. (2001). Molecular basis of aggression. Trends Neurosci. 24, 713-719. doi: 10.1016/S0166-2236(00)01996-2

Nonacs, P., and Kapheim, K. M. (2007). Social heterosis and the maintenance of genetic diversity. J. Evol. Biol. 20, 2253-2265. doi: 10.1111/j.14209101.2007.01418.x

Nonacs, P., and Kapheim, K. M. (2008). Social heterosis and the maintenance of genetic diversity at the genome level. J. Evol. Biol. 21, 631-635. doi: 10.1111/j.1420-9101.2007.01489.x

Oers, K., van, Jong, G., de, Noordwijk, A. J., van, Kempenaers, B., and Drent, P. J. (2005). Contribution of genetics to the study of animal personalities: a review of case studies. Behaviour 142, 1185-1206. doi: 10.1163/156853905774539364

Oldroyd, B. P., and Fewell, J. H. (2007). Genetic diversity promotes homeostasis in insect colonies. Trends Ecol. Evol. 22, 408-413. doi: 10.1016/j.tree.2007.06.001

Page, R. E., and Fondrk, M. K. (1995). The effects of colony-level selection on the social organization of honey bee (Apis mellifera L.) colonies: colonylevel components of pollen hoarding. Behav. Ecol. Sociobiol. 36, 135-144. doi: 10.1007/BF00170718 
Page, R. E., Fondrk, M. K., and Rueppell, O. (2012). Complex pleiotropy characterizes the pollen hoarding syndrome in honey bees (Apis mellifera L.). Behav. Ecol. Sociobiol. 66, 1459-1466. doi: 10.1007/s00265-012-1400-x

Page, R. E., and Robinson, G. E. (1991). The genetics of division of labour in honey bee colonies. Adv. Insect Physiol. 23, 117-169. doi: 10.1016/S00652806(08)60093-4

Pamminger, T., Modlmeier, A. P., Suette, S., Pennings, P. S., and Foitzik, S. (2012). Raiders from the sky: slavemaker founding queens select for aggressive host colonies. Biol. Lett. 8, 748-750. doi: 10.1098/rsbl.2012.0499

Pamminger, T., Scharf, I., Pennings, P. S., and Foitzik, S. (2011). Increased host aggression as an induced defense against slave-making ants. Behav. Ecol. 22, 255-260. doi: 10.1093/beheco/arq191

Pearce, A. N., Huang, Z. Y., and Breed, M. D. (2001). Juvenile hormone and aggression in honey bees. J. Insect Physiol. 47, 1243-1247. doi: 10.1016/S00221910(01)00109-3

Petelle, M. B., McCoy, D. E., Alejandro, V., Martin, J. G. A., and Blumstein, D. T. (2013). Development of boldness and docility in yellow-bellied marmots. Anim. Behav. 86, 1147-1154. doi: 10.1016/j.anbehav.2013.09.016

Pinter-Wollman, N., Gordon, D. M., and Holmes, S. (2012a). Nest site and weather affect the personality of harvester ant colonies. Behav. Ecol. 23, 1022-1029. doi: 10.1093/beheco/ars066

Pinter-Wollman, N., Hubler, J., Holley, J.-A., Franks, N. R., and Dornhaus, A. (2012b). How is activity distributed among and within tasks in Temnothorax ants? Behav. Ecol. Sociobiol. 66, 1407-1420. doi: 10.1007/s00265-0121396-2

Pruitt, J. N. (2012). Behavioural traits of colony founders affect the life history of their colonies. Ecol. Lett. 15, 1026-1032. doi: 10.1111/j.1461-0248.2012.01825.x

Pruitt, J. N. (2013). A real-time eco-evolutionary dead-end strategy is mediated by the traits of lineage progenitors and interactions with colony invaders. Ecol. Lett. 16, 879-886. doi: 10.1111/ele.12123

Pruitt, J. N., and Goodnight, C. (2014). Site-specific group selection drives locally adapted colony compositions. Nature 514, 359-362 doi: 10.1038/nature13811

Pruitt, J. N., and Riechert, S. E. (2011). Within-group behavioral variation promotes biased task performance and the emergence of a defensive caste in a social spider. Behav. Ecol. Sociobiol. 65, 1055-1060. doi: 10.1007/s00265-010-1112-z

Pull, C. D., Hughes, W. O. H., and Brown, M. J. F. (2013). Tolerating an infection: an indirect benefit of co-founding queen associations in the ant Lasius niger. Naturwissenschaften 100, 1125-1136. doi: 10.1007/s00114-013-1115-5

Raine, N. E., and Chittka, L. (2007). The adaptive significance of sensory bias in a foraging context: floral colour preferences in the bumblebee Bombus terrestris. PLOS ONE 2:e556. doi: 10.1371/journal.pone.0000556

Richard, F.-J., and Hunt, J. H. (2013). Intracolony chemical communication in social insects. Insectes Sociaux 60, 275-291. doi: 10.1007/s00040-013-0306-6

Johnson, B. R., and Linksvayer, T. A. (2010). Deconstructing the superorganism: social physiology, groundplans, and sociogenomics. Q. Rev. Biol. 85, 57-79. doi: $10.1086 / 650360$

Robinson, G. E. (1992). Regulation of division of labor in insect societies. Annu. Rev. Entomol. 37, 637-665. doi: 10.1146/annurev.en.37.010192.003225

Saltz, J. B. (2013). Genetic composition of social groups influences male aggressive behaviour and fitness in natural genotypes of Drosophila melanogaster. Proc. $R$. Soc. B Biol. Sci. 280:20131926. doi: 10.1098/rspb.2013.1926

Saltz, J. B., and Nuzhdin, S. V. (2014). Genetic variation in niche construction: implications for development and evolutionary genetics. Trends Ecol. Evol. 29, 8-14. doi: 10.1016/j.tree.2013.09.011

Sasaki, T., Granovskiy, B., Mann, R. P., Sumpter, D. J. T., and Pratt, S. C. (2013). Ant colonies outperform individuals when a sensory discrimination task is difficult but not when it is easy. Proc. Natl. Acad. Sci. U.S.A. 110, 13769-13773. doi: $10.1073 /$ pnas. 1304917110

Sasaki, T., and Pratt, S. C. (2011). Emergence of group rationality from irrational individuals. Behav. Ecol. 22, 276-281. doi: 10.1093/beheco/arq198

Scharf, I., Modlmeier, A. P., Fries, S., Tirard, C., and Foitzik, S. (2012). Characterizing the collective personality of ant societies: aggressive colonies do not abandon their home. PLoS ONE 7:e33314. doi: 10.1371/journal.pone.0 033314

Sih, A., Bell, A., and Johnson, J. C. (2004). Behavioral syndromes: an ecological and evolutionary overview. Trends Ecol. Evol. 19, 372-378. doi: 10.1016/j.tree.2004.04.009

Simons, A. M. (2004). Many wrongs: the advantage of group navigation. Trends Ecol. Evol. 19, 453-455. doi: 10.1016/j.tree.2004.07.001
Sinha, S. (2006). "The apparent madness of crowds: irrational collective behavior emerging from interactions among rational agents," in Econophysics of Stock and Other Markets New Economic Windows, eds A. Chatterjee and B. K. Chakrabarti (Milan: Springer), 159-162. Available online at: http://link.springer.com/chapter/10.1007/978-88-470-0502-0_16 (Accessed October 28, 2014).

Sinn, D. L., Gosling, S. D., and Moltschaniwskyj, N. A. (2008). Development of shy/bold behaviour in squid: context-specific phenotypes associated with developmental plasticity. Anim. Behav. 75, 433-442. doi: 10.1016/j.anbehav.2007.05.008

Smith, B. R., and Blumstein, D. T. (2008). Fitness consequences of personality: a meta-analysis. Behav. Ecol. 19, 448-455. doi: 10.1093/beheco/arm144

Stamps, J., and Groothuis, T. G. G. (2010). The development of animal personality: relevance, concepts and perspectives. Biol. Rev. 85, 301-325. doi: 10.1111/j.1469-185X.2009.00103.x

Suryanarayanan, S., Hantschel, A. E., Torres, C. G., and Jeanne, R. L. (2011a). Changes in the temporal pattern of antennal drumming behavior across the Polistes fuscatus colony cycle (Hymenoptera, Vespidae). Insectes Sociaux 58, 97-106. doi: 10.1007/s00040-010-0122-1

Suryanarayanan, S., Hermanson, J. C., and Jeanne, R. L. (2011b). A mechanical signal biases caste development in a social wasp. Curr. Biol. 21, 231-235. doi: 10.1016/i.cub.2011.01.003

Szathmáry, E., and Smith, J. M. (1995). The major evolutionary transitions. Nature 374, 227-232. doi: 10.1038/374227a0

Tobback, J., Heylen, K., Gobin, B., Wenseleers, T., Billen, J., Arckens, L., et al. (2008). Cloning and expression of PKG, a candidate foraging regulating gene in Vespula vulgaris. Anim. Biol. 58, 341-351. doi: 10.1163/157075608X3 83665

Toth, A. L., Bilof, K. B. J., Henshaw, M. T., Hunt, J. H., and Robinson, G. E. (2009). Lipid stores, ovary development, and brain gene expression in Polistes metricus females. Insectes Sociaux 56, 77-84. doi: 10.1007/s00040-008-1041-2

Toth, A. L., and Robinson, G. E. (2007). Evo-devo and the evolution of social behavior. Trends Genet. 23, 334-341. doi: 10.1016/j.tig.2007.05.001

Toth, A. L., Tooker, J. F., Radhakrishnan, S., Minard, R., Henshaw, M. T., and Grozinger, C. M. (2014). Shared genes related to aggression, rather than chemical communication, are associated with reproductive dominance in paper wasps (Polistes metricus). BMC Genomics 15:75. doi: 10.1186/1471-2164-15-75

Toth, A. L., Varala, K., Henshaw, M. T., Rodriguez-Zas, S. L., Hudson, M. E., and Robinson, G. E. (2010). Brain transcriptomic analysis in paper wasps identifies genes associated with behaviour across social insect lineages. Proc. R. Soc. B Biol. Sci. 277, 2139-2148. doi: 10.1098/rspb.2010.0090

Tschinkel, W. R. (1993). Resource allocation, brood production and cannibalism during colony founding in the fire ant, Solenopsis invicta. Behav. Ecol. Sociobiol. 33, 209-223. doi: 10.1007/BF02027118

Verbeek, M. E. M., Drent, P. J., and Wiepkema, P. R. (1994). Consistent individual differences in early exploratory behaviour of male great tits. Anim. Behav. 48, 1113-1121. doi: 10.1006/anbe.1994.1344

Viggiano, D., Vallone, D., Welzl, H., and Sadile, A. G. (2002). The naples highand low-excitability rats: selective breeding, behavioral profile, morphometry, and molecular biology of the mesocortical dopamine system. Behav. Genet. 32, 315-333. doi: 10.1023/A:1020210221156

Vital, C., and Martins, E. P. (2013). Socially-central zebrafish influence group behavior more than those on the social periphery. PLOS ONE 8:e55503. doi: 10.1371/journal.pone.0055503

Vos, M., and Velicer, G. J. (2006). Genetic population structure of the soil bacterium Myxococcus xanthus at the centimeter scale. Appl. Environ. Microbiol. 72, 3615-3625. doi: 10.1128/AEM.72.5.3615-3625.2006

Voss, S. H., and Blum, M. S. (1987). Trophic and embryonated egg production in founding colonies of the fire ant Solenopsis invicta (Hymenoptera: Formicidae). Sociobiology. 13, 271-278.

Wang, J., Ross, K. G., and Keller, L. (2008). Genome-wide expression patterns and the genetic architecture of a fundamental social trait. PLoS Genet. 4:e1000127. doi: 10.1371 /journal.pgen.1000127

Weiss, A., King, J. E., and Figueredo, A. J. (2000). The heritability of personality factors in chimpanzees (Pan troglodytes). Behav. Genet. 30, 213-221. doi: 10.1023/A:1001966224914

Whitfield, C. W., Ben-Shahar, Y., Brillet, C., Leoncini, I., Crauser, D., LeConte, Y., et al. (2006). Genomic dissection of behavioral maturation in the honey bee. Proc. Natl. Acad. Sci. U.S.A. 103, 16068-16075. doi: 10.1073/pnas.0606909103 
Whitfield, C. W., Cziko, A.-M., and Robinson, G. E. (2003). Gene expression profiles in the brain predict behavior in individual honey bees. Science 302, 296-299. doi: 10.1126/science.1086807

Wiernasz, D. C., and Cole, B. J. (1995). Spatial distribution of Pogonomyrmex occidentalis: recruitment, mortality and overdispersion. J. Anim. Ecol. 64, 519-527. doi: $10.2307 / 5654$

Wilson, A. D. M., and Krause, J. (2012). Personality and metamorphosis: is behavioral variation consistent across ontogenetic niche shifts? Behav. Ecol. 23, 1316-1323. doi: 10.1093/beheco/ars123

Wilson, E. O. (1975). Sociobiology. Cambridge, MA: The New Synthesis (Belk-nap/Harvard University Press).

Wilson, E. O. (1985). The sociogenesis of insect colonies. Science 228, 1489-1495. doi: 10.1126/science.228.4707.1489

Wilson, E. O. (1987). Causes of ecological success: the case of the ants. J. Anim. Ecol. 56, 1-9. doi: $10.2307 / 4795$

Wilson, E. O., and Hölldobler, B. (2005). The rise of the ants: a phylogenetic and ecological explanation. Proc. Natl. Acad. Sci. U.S.A. 102, 7411-7414. doi: 10.1073/pnas.0502264102

Wooding, S., Bufe, B., Grassi, C., Howard, M. T., Stone, A. C., Vazquez, M., et al. (2006). Independent evolution of bitter-taste sensitivity in humans and chimpanzees. Nature 440, 930-934. doi: 10.1038/nature 04655

Wray, M. K., Mattila, H. R., and Seeley, T. D. (2011). Collective personalities in honeybee colonies are linked to colony fitness. Anim. Behav. 81, 559-568. doi: 10.1016/j.anbehav.2010.11.027
Wray, M. K., and Seeley, T. D. (2011). Consistent personality differences in house-hunting behavior but not decision speed in swarms of honey bees (Apis mellifera). Behav. Ecol. Sociobiol. 65, 2061-2070. doi: 10.1007/s00265-0111215-1

Zayed, A., and Robinson, G. E. (2012). Understanding the relationship between brain gene expression and social behavior: lessons from the honey bee. Annu. Rev. Genet. 46, 591-615. doi: 10.1146/annurev-genet-110711-155517

Conflict of Interest Statement: The authors declare that the research was conducted in the absence of any commercial or financial relationships that could be construed as a potential conflict of interest.

Received: 05 October 2014; accepted: 25 November 2014; published online: 10 December 2014.

Citation: Bengston SE and Jandt JM (2014) The development of collective personality: the ontogenetic drivers of behavioral variation across groups. Front. Ecol. Evol. 2:81. doi: 10.3389/fevo.2014.00081

This article was submitted to Behavioral and Evolutionary Ecology, a section of the journal Frontiers in Ecology and Evolution.

Copyright (c) 2014 Bengston and Jandt. This is an open-access article distributed under the terms of the Creative Commons Attribution License (CC BY). The use, distribution or reproduction in other forums is permitted, provided the original author(s) or licensor are credited and that the original publication in this journal is cited, in accordance with accepted academic practice. No use, distribution or reproduction is permitted which does not comply with these terms. 